\title{
Analysis of Watershed Characteristics and Spatial Soil Loss Estimation: A case Fincha Watershed, Western Ethiopia
}

Seifu Kebede Debela ( $\sim$ kebed2seif@gmail.com )

Jimma University Institute of Technology

\section{Fekadu Fufa}

Jimma University Institute of Technology

\section{Research}

Keywords: Land use/cover, Sub-basins, Soil Type, Soil Loss, Watershed Characteristics

Posted Date: October 9th, 2020

DOI: https://doi.org/10.21203/rs.3.rs-87565/v1

License: (c) (1) This work is licensed under a Creative Commons Attribution 4.0 International License.

Read Full License 


\section{Abstract}

Characteristics of watershed were not well investigated as global also in Fincha, Ethiopia. Fincha watershed is the most erosion prone area in the highlands of Ethiopia towards to Fincha dam.Therefore, the aim of this study was toanalysisFincha watershed characteristics based on land use/cover, soil type and slope classification and to identify soil erosionpronearea using Arc-GIS and Arc-SWAT model.Accordingly, nine major land use/covers were identified. Those were:- bush land, dominantly cultivated, moderately cultivated, irrigated land, grass land, water bodies, swamp area, urban and woodland open. From these most part of the catchment was under cultivation with $67.677 \%$ of the total area. In the same way, the major soil types identified were: - chromic luvisols, chromic vertisols, dystric cambisols, eutric cambisols, eutric nitosols, eutric regosols, haplic phaeozems, humic cambisols and water. Cambisols were covered the highest percentage, $39.98 \%$ area of the catchment.Subsequently, average annual values of estimated soil lossfrom the catchment was 231.2 ton/ha.The identified prone erosion areas were sub-basins $1,8,11,14,17$ and 20 . It was very critical for environmentalists, hydrologists, agricultural experts, watershed managements and concerned decision makers for sustainable water resource projects and environmental protection system. Therefore, further detail investigation and appropriate watershed management practices should be given for these subbasins.

\section{Introduction}

An area that contains a common set of stearms and rivers into a single water bodies is called watershed. So,characterization of watershed is a necessary and important step in planning and management of a watershed. Miller et al, (2003) stated that, many researchers have used DEM and GIS techniques for watershed delineation and extraction of drainage networks and various topographic characteristics of a watershed.Automatic extraction of important watershed characteristics such as watershed drainage area/boundary, field and channel slope, aspect, and drainage network using DEM $30 \mathrm{~m}$ were most accurately with variations less than $10 \%$ (Singh et al., 2005).

Arc GIS was used to extract hydrological characteristics such as flow direction, flow accumulation, flow length, stream networks, and snap pour point of various streams (Fu-quan et al., 2010). Gossa W, (2011), globally soil degradation is affecting 1.9 billion hectares and is increased at a rate of 5 to 7 million ha/yr. In most parts of Ethiopia the high intensity rainfall occurs when the cultivated land has low cover, which can reduce the impact of the high intensity raindrop and the high runoff which can be slowed by soil cover (White, 2005).Soil erosion and river sedimentation can cause critical environmental, ecological and economic problems worldwide (Yang et al., 2003). Soil erosion from the upstream area of the Blue Nile River Basin and the subsequent sedimentation in its downstream area caused a rapid loss of storage volume due to excessive sedimentation (Betrie GD et al., 2011).

Bezuayehu (2006) reported that Fincha watershed is a typical example of many watersheds in the country that had undergone land use change and presently undergoing environmental degradation and causing serious problems. It is one of those highland areas of the country with severe soil erosion 
problem draining to the Nile River. Fincha hydropower reservoir is a highland area with a severe soil erosion problem that drains to the Blue Nile River due to increasingly mountainous and steeper slopes area cultivated, in many cases without protective measures against land erosion and degradation (Assefa, 1994).

Soil loss from watershed was increased from time to time due natural and human induce activities.Reduction in storage capacity of rivers and reservoirs become increased due to soil loss and sediment yield from the catchment (Agarwal, et al., 2009). So,characterization of watershed, soil losses, sediment yields,reservoir capacity reduction, disturbance of aquatic ecosystem and watershed managements were main agendas of scientific researchers.

Since erosion and Sediment yield is one of the most complex natural processes and many factors are involved in it, the full knowledge of the factors influencing this phenomenon is very difficult (Zahabioun et al., 2010).

Analysis of watershed characteristics, soil erosion, transport and deposition of sediments in reservoirs, irrigation canals and hydropower systems were very essential for land and water management, but these were not studied in-depth in the catchment.

So, watershed characterizations, spatial distributions of soil losses and prone area identification of Fincha catchment using GIS and SWAT model was pertinent for best watershed management practices, planning, implementation, decision making, giving solution for future.

\section{Study Area}

The study area is situated in Abay/Nile River basin which is located in the Horro Guduru Wollegga Zone, Oromia National Regional State, Ethiopia. Geographically located between $9^{\circ} 9^{\prime} 53^{\prime \prime} \mathrm{N}$ to $10^{\circ} 1{ }^{\prime} 00^{\prime \prime} \mathrm{N}$ latitudes and $37^{\circ} 00^{\prime} 25^{\prime \prime} \mathrm{E}$ to $37^{\circ} 33^{\prime} 17^{\prime \prime} \mathrm{E}$ longitudesas shown in Fig. 1. The altitude in the catchment ranges from $902 \mathrm{~m}$ in the lowlands up to $3,171 \mathrm{~m}$ amsl in the highlands. The climate of the Fincha watershed is tropical highland monsoon with an average annual rainfall of $1763.6 \mathrm{~mm}$ and mean monthly temperature of the area varies from 14.6 to $17.7^{\circ} \mathrm{C}$. Most of the rain falls during the months of June to September with peaks occurring during July to August and it is virtually somewhat dry from November through to April.The total area of watershed was $2,619 \mathrm{~km}^{2}$ and six districts-namely, Jimma Geneti, Horro, AbbayChomen, AbaboGuduru, Guduru, and Jimma Rare. The watershed is bordered on the north by the Blue Nile River (also called Abbay River in Ethiopia), on the east by the Guder River Basin, on the south by Awash River Basin, and on the west by Diddessa River Basin.

\section{Materials And Methods}

Majority of data used were secondary data that includes meteorological, spatial and hydrological data in general. Those, data were collected from different organizations like Ethiopia National Metrological Agency and from Ministry of Water, Irrigation and Electricity. Also field observation was done for locating 
the outlet and visualizing the catchment.The main tools that have been used in this study for data collection, preparation and analysiswere: Arc VIEW GIS10.4, Arc SWAT2012, different maps, andMicrosoft excel. ArcGIS10.4 was used for creating maps, managing geographic information in a database and execution of GIS processing tools (such as clipping, overlay, and spatial analysis). SWAT2012 model was used for setting up the study project, delineating the study area, analysing HRU, writing all input tables, editing inputs and simulating all inputs.

\subsection{Model inputs and their compatibility for the model}

Three main input data were 1) metrological data 2) spatial data

Table 1

Metrological data and their format

\begin{tabular}{|ll|}
\hline Input data & Compatibility format \\
\hline Daily precipitation & Txt \\
\hline Daily temp (max and min) & Txt \\
\hline Solar radiation & Txt \\
\hline Relative humidity & Txt \\
\hline Wind speed & Txt \\
\hline
\end{tabular}

Table 2

Spatial data and their format

\begin{tabular}{|ll|}
\hline Input & Format \\
\hline DEM & Grid \\
\hline LULC map & Grid/Shape file \\
\hline Soil map & Grid/Shape file \\
\hline Stream network layers & Shape file \\
\hline
\end{tabular}

In SWAT model watershed can be automatically delineated by importing the digital elevation model (DEM) and adjusting the threshold area or provide predefined sub watersheds. The land area in a sub watershed was divided into several hydrologic response units (HRUs). HRUs are portions of a sub watershed and possess unique land use, slope range, and soil attributes (Neitsch et al., 2005).

\section{Results And Discussion 4.1 Topography of the study}


The topography of the Fincha watershed signifies two distinct features: the highlands, ragged mountainous area in the upper and western part of the watershed and the lowland valley area with flat topography in the lower part of the watershed. The altitude in the watershed ranges from $902 \mathrm{~m}$ to $3,171 \mathrm{~m}$ amsl. Elevation of the study area was classified into four classes. Majority of the watershed area was situated in ranges of 2,005.4 to 2,388 $\mathrm{m}$ amsl as shown in Fig. 3 .

\subsection{Watershed Delineation process}

The Arc SWAT requires model setup and parameterization of the model. Watershed was automatically delineated using $30 \mathrm{~m} \times 30 \mathrm{~m}$ DEM.

Automatically delineated the watershed was classified into several hydrologically connected subwatersheds. After the DEM grid loaded and the stream networks superimposed, the DEM map grid was prepared to remove the non-draining zones. The initial stream network and sub-basin outlets also defined based on drainage area threshold approach. Sub-basin parameters were calculated in order to estimate the basic watershed characteristics from the DEM and 21 sub-basins with different HRU were identified. General procedure of watershed delineation was presented as Fig. 4 below.

\subsection{HRUs analysis}

It includes requires land use/cover, soil and slope layers and their threshold inputs. HRU is defined as a lumped land area comprised of a uniform land use land cover, soil type and uniform slope of the watershed. Land use/cover, soil type, runoff, soil loss and sediment yield could be predicted separately from each HRU.It increases the accuracy in prediction that provides a much better physical description of the water balance rather than prediction from the whole catchment at once.

\subsubsection{Land use/land cover analysis}

The LULC is one of the most important watershed characteristics and factors that affect soil erosion, runoff, sediment and evapo-transpiration in a watershed during simulation (Neitsch et al., 2005). For LULC analysis of the catchment, the land use map Ethiopia and Fincha basin were overlaid and clipped. There were nine major land use land cover classes were identified in Fincha watershed. Those were:- bush land, dominantly cultivated, moderately cultivated, irrigated land, grass land, water bodies, swampy area, urban and woodland that presented in Table 3 and Fig. 5 respectively.Bush land occupies about $2.13 \%$ of total area. These were type of vegetation which is either a remainder of natural vegetation of the land or, if altered, was still representative of the structure and floristic of natural vegetation. Part of the watershed covered by grasslands was $10.64 \%$. Are types of vegetation dominated by grasses rather than large shrubs or trees. As degradation of grassland increase, soil erosion also increased. Water bodies occupied $11.42 \%$ of total area. Due to poor watershed management, quality of these water bodies decreased and aquatic ecosystems was disturbed. Similarly, swamp area, urban and woodland open covered $2.533 \%$, $1.54 \%$ and $4.06 \%$ respectively. About $67.677 \%$ of the total catchment was under human induces, 
cultivation practices. These indicate thatmajority of the catchment was very sensitive to runoff, soil erosion/sediment yield due to cultivation practices.Therefore, best watershed management practices should be applied to protect this watershed by concerned stakeholders.

Table 3

Major land use/cover classes in Fincha watershed

\begin{tabular}{|llll|}
\hline S.No & Land use/cover category & Area covered $\left(\mathrm{Km}^{2}\right)$ & Watershed area(\%) \\
\hline 1 & Bush land & 55.785 & 2.13 \\
\hline 2 & Dominantly cultivated & 958.519 & 36.599 \\
\hline 3 & Moderately cultivated & 763.123 & 29.138 \\
\hline 4 & Irrigated land & 50.720 & 1.94 \\
\hline 5 & Grass land & 278.669 & 10.64 \\
\hline 6 & Water bodies & 298.987 & 11.42 \\
\hline 7 & Swamp area & 66.34 & 2.533 \\
\hline 8 & Urban & 40.332 & 1.54 \\
\hline 9 & Woodland open & 106.332 & 4.06 \\
\hline Total & & 2,619 & $100 \%$ \\
\hline
\end{tabular}

\subsubsection{Soil type analysis}

Arc SWAT model require soil data to provide both the distribution of the soil type in the watershed and the various parameters describing the soils hydrological and textural properties. The soil textural and physicochemical properties include soil texture, available water content, hydraulic conductivity, bulk density and organic carbon content for each soil type.Fincha basin was overlaid with Ethio - soil map and clipped.

Clipped Fincha soil map was projected to UTM zone 37, projection area of Ethiopia and nine major soil types were obtained. These soil categories and spatial distribution of the catchment was presented in Table 4 and Fig. 7 respectively.

These major soils were: chromic luvisols, chromic vertisols, dystric cambisols, eutric cambisols, eutric nitosols, eutric regosols, haplic phaeozems, humic cambisols and water. From these, soil type that covers most part of the watershed were dystric and eutric cambisols with $39.98 \%$ of a total area.As of the soil properties, cambisols show variations in colors, structure and carbon. They have medium to fine textured materials that result from the decomposition of a wide range of rocks. Cambisols exist on a level to mountainous topography of all-weather climates. 
They are favorable for a wide range of vegetation growth and have good production potential for agricultural activities. Under uncontrolled agricultural activities and poor land management, the soil was exposed to a high potential of erosion occurrence and sediment yield. The second soil class was eutric regosols and eutric nitosols with $21.65 \%$ of total area of the watershed. Regosols are very weakly developed mineral soils in unconsolidated materials that have only an ochric surface horizon and that are very deep. They are extensive in eroding lands, in particular in arid and semi-arid areas and in mountain regions.

Nitosols mostly found at higher altitudes. They are inherently fertile of the tropical soils because of their high nutrient contents and deep, permeable structure and exploited widely for plantation agriculture.

The third category was chromic vertisols and chromic luvisols that cover $20.27 \%$ of the watershed.The reference soil group of Luvisols holds soils whose dominant characteristics is a marked textural differentiation within the soil profile, with the surface horizon being depleted of clay and accumulation of clay in a subsurface argic horizon. Most chromic luvisols were well drained but shallow groundwater may occur in luvisols in depression area. From soil properties these soils have high activity clays throughout and lack the abrupt textural change of planosols. Luvisols are fertile soils and suitable for a wide range of agricultural use when in controlled system. So, under poor watershed management clay will be washed down from the surface soil to accumulation horizon at lower depth.

Table 4

Soil category of Fincha watershed

\begin{tabular}{|llll|}
\hline S.No & Soil category & Covered area $\left(\mathrm{Km}^{2}\right)$ & Watershed area $(\%)$ \\
\hline 1 & Chromic Luvisols & 2.5955 & 0.1 \\
\hline 2 & Chromic Vertisols & 528.3573 & 20.17 \\
\hline 3 & Dystric Cambisols & 620.6453 & 23.7 \\
\hline 4 & Eutric Cambisols & 426.269 & 16.28 \\
\hline 5 & Eutric Nitosols & 21.823 & 0.83 \\
\hline 6 & Eutric Regosols & 545.178 & 20.82 \\
\hline 7 & Haplic Phaeozems & 34.837 & 1.33 \\
\hline 8 & Humic Cambisols & 132.969 & 5.08 \\
\hline 9 & Water & 306.377 & 11.7 \\
\hline Total & & 2,619 & $100 \%$ \\
\hline
\end{tabular}

\subsubsection{Slope analysis}


Slope was another watershed characteristics and critical for watershed management. As the slope of the catchment became steep, runoff and soil erosion were increased. Example, sub-watershed with steep slope might contribute more soil losses, sediment yield to water bodies than with flat landscapes.

The slope of the catchment was classified into four multiple classes $0-3 \%, 3-6 \%, 6-9 \%$ and above $9 \%$ based on the DEM data used during the watershed delineation and the topography of the catchment and shown in Fig. 8.

General flat slope covers about $56.43 \%$, moderate slope $28.54 \%$ and steep slope $15.03 \%$ of the total catchment. These indicate that of the catchment area had high general flat.

Table 5

Slope classes in Fincha watershed

\begin{tabular}{|llll|}
\hline S.No & Slope class (degree) & Covered Area $\left(\mathrm{Km}^{2}\right)$ & Watershed area $(\%)$ \\
\hline 1 & $0-3$ & 393.6564 & 15.03 \\
\hline 2 & $3-6$ & 414.3073 & 15.82 \\
\hline 3 & $6-9$ & 333.1661 & 12.72 \\
4 & $>9$ & $1,477.9198$ & 56.43 \\
\hline Total & & 2,619 & $100 \%$ \\
\hline
\end{tabular}

\subsection{Soil loss discussion at HRU and Sub basinlevel}

The assessment of the spatial variability of sediment yield at HRU and sub basin level is useful for catchment management planning and reservoir protection. At sub basin level the highest and lowest average sediment yield was from sub basin 11 and sub basin 18 with values of 582.022 ton/ha and 0 ton/ha respectively.

This indicates sub basin 11 was under extreme soil erosion and the most prone area of Fincha watershed at sub basin level from a total of 21 sub basins.So,priority of watershed management practices at subbasin level should start from this subbasin and proceed to the rest. The spatial prone area in relation to soil erosion of Fincha watershed was shown in Fig. 9.

Soil erosion prone area was classified based on the classifications of erosion rates in the Ethiopian high lands. It was classified into four main classes in this study as very high, high, medium and low. Very high from sub-basin 1, 8, 11, 14, 17 and 20that covers an area of $27.84 \%$. High erosion level from sub-basin 3 , $7,9,12,13,15$ and16 with covered area of $36.03 \%$. Medium erosion level from sub-basin 4, 5, 6,10 and covers area of $24.24 \%$. The last classification as low was from sub-basin 2, 18, 1921 and covers an area of $11.9 \%$. The average annual sediment yield total sub basins is $231.2 \mathrm{ton} / \mathrm{ha}$. The statistical data of the soil loss class and corresponding area ratios were presented in Table 6. 
Table 6

Statistical data of the soil loss class and corresponding area ratios

\begin{tabular}{|llll|}
\hline Soil loss classes & Soil loss rate (ton/ha/yr) & Sub basins & Area ratio (\%) \\
\hline Low & $<105$ & $2,18,19$ and 21 & 11.9 \\
\hline Medium & $105-202$ & $4,5,6$ and 10 & 24.24 \\
\hline High & $202-358.3$ & $3,7,9,12,13,15$ and 16 & 36.03 \\
\hline Very high & $358.3-582$ & $1,8,11,14,17$ and 20 & 28 \\
\hline
\end{tabular}

\section{Conclusions}

The watershed was classified into 21 subbasins, $205 \mathrm{HRUs}$ with a total area of 2,619 $\mathrm{Km}^{2}$. From the results, there are nine land use land cover and nine major soil types were obtained. According to LULC analysis, about $67.677 \%$ of the Fincha watershed was under cultivation practice. Due to this activity the catchment can be easily exposed to runoff, soil erosion and sediment yield if best watershed management practice will not implemented. As so analysis, Cambisols were major soil types of the catchment and covered around 39.98\% of the total area. Sub-basins 1, 8,11, 14, 17 and 20 were the most prone erosion areas of the watershed in relative to the other subbasins and occupied about $27.84 \%$ of the catchment. So, best watershed management practice should be recommended for Fincha watershed by conserned bodies.

\section{Declarations}

\subsection{Availability of data and materials}

All data generated or analysed during this study are included in this manuscript and it can be found from outhors if required latter.

\subsection{Competing interests}

As authors, we have no competing interests to disclosure our submitted article in this section.

\subsection{Funding}

Publication costs for Sustainable Environment Research will be covered by the Chinese Institute of Environmental Engineering so authors do not need to pay an article-processing charge.

\subsection{Authors' contributions}

SK literarure review, data collection, analyzed and interpreted the required data accordingly regarding with LULC analysis, soil type analysis and soil loss estimation and major contributor in writing the manuscript. 
FF performed on check up and comments, writing the manuscript. Finally, all authors read and approved the final manuscript.

\subsection{Acknowledgements}

First and above all praise to be Almighty God, for endless love and for He gives me healthy mind to think and to do my works and great thanks be to Him forever.

My special and deep thanks goes to my parents for their encouragement, love and advices.

I heartedly gratify my lovely wife Derartu Bultum, who has took double responsibility of handling issues of family and successful accomplishment of my vision.

Also, I would like apreatiate Sustainable Environment Research for giving me such opportunity to publish my original paper

\section{References}

Agarwal, A. (2009). Forecasting of Runoff and Sediment Yield Using artificial Neural Networks. Journal of Water Resource and Protection1, 368-375.

Ananda, J. (2003). Soil erosion in developing countries. Journal of Environmental Management, 343353.

Arnhold, S. (2014). Soil erosion and conservation potential for row crop cultivation. Geoderma, 89-105.

Betrie GD. (2011). Sediment management modeling in the Blue Nile Basin using SWATmodel. Hydrol Earth Syst Sci.

David, M. (2014). Simulation of medium-term soil redistributions for different land use and landscape design scenarios within a vineyard landscape in Mediterranean France. Geomorphology, 10-21.

Dercon, G. (2012). Fallout radionuclide-based techniques for assessing the impact of soil conservation measures on erosion control and soil quality:. Fallout radionuclide-based techniques for assessing the impact of soil conservation measures on erosion control and soil quality:; 78-85.

Eckhardt K. (2001). Automatic calibration of a distributed catchment. Journal of Hydrology, 103-109.

Fu-quan, N; Yao-sheng, T; Li-ping, X and Cheng-wei F. (2010). DEM and ArcGIS-Based Extraction of EcoHydrological Characteristics in Ya'an, China. 2nd International Workshop on Intelligent Systems and Applications (ISA), 22-23 May, 2010, pp.1-5. DOI: 10.1109/IWISA.2010.5473679

Fontaine TA. (2002). Development of a snowfall-snowmelt routine for mountainous terrain for the soil water assessment tool (SWAT). Journal of Hydrology, 209-223. 
GD, B. (2011). Sediment management modeling in the Blue Nile Basin using SWATmode. Hydrol Earth Syst Sci, 15-807

Gossa Wordofa. Soil erosion modeling using GIS and RUSLE on the eurajoki watershed. Finland: Temered University, 2011

Jabbari, I. (2003). Estimation of soil erosion and sediment yield by measuring a shower. Geographical Research Quarterly, 53-74.

Javadi M. (2011). Comparison between estimations of the suspended sediment potential in various units using a rainfall simulator in Namehrood,. the Natural Resources Science and Technology, 14-21.

Lopez-Vicente. (2013). Predicting runoff and sediment connectivity and soil erosion by water for different land use scenarios. CATENA, 62-73

Maathuis, B.H.P. (2006). Digital Elevation model based hydro-processing.Geocarto International, 21: 2126.

Miller, S.N, Guertin, D.P. and Goodrich, D.C. (2003). Deriving stream channel morphology using GIS based watershed analysis. In: J.G. Lyon, (editor), GIS for Water Resources and Watershed Management, Taylor and Francis, London.

Ndomba, P. (2007). The Suitability of SWAT Model in Sediment Yield Modelling for Ungauged Catchments. Proceedings of the 3rd International SWAT conference.

Pandey, V.K., Pandey, A. and Panda, S.N. (2007). Application of remote sensing and GIS for watershed characterization: a case study of Banikdih watershed (Eastern India). Asian Journal of Geoinformatics, 7(1):3-15.

Saxton, K. E. (2006). Soil and water characteristics,. Agricultural Research Service.

Setegn SG. (2008). Hydrological Modeling in the Lake Tana Basin, Ethiopia Using SWAT Model. Open Hydrology Journal, 49-62

Singh, R., Tiwari, K.N. and Mal, B.C. (2005). Hydrological studies for small watershed in India using the ANSWERS model. Journal of Hydrology, 318: 184-199.

\section{Figures}



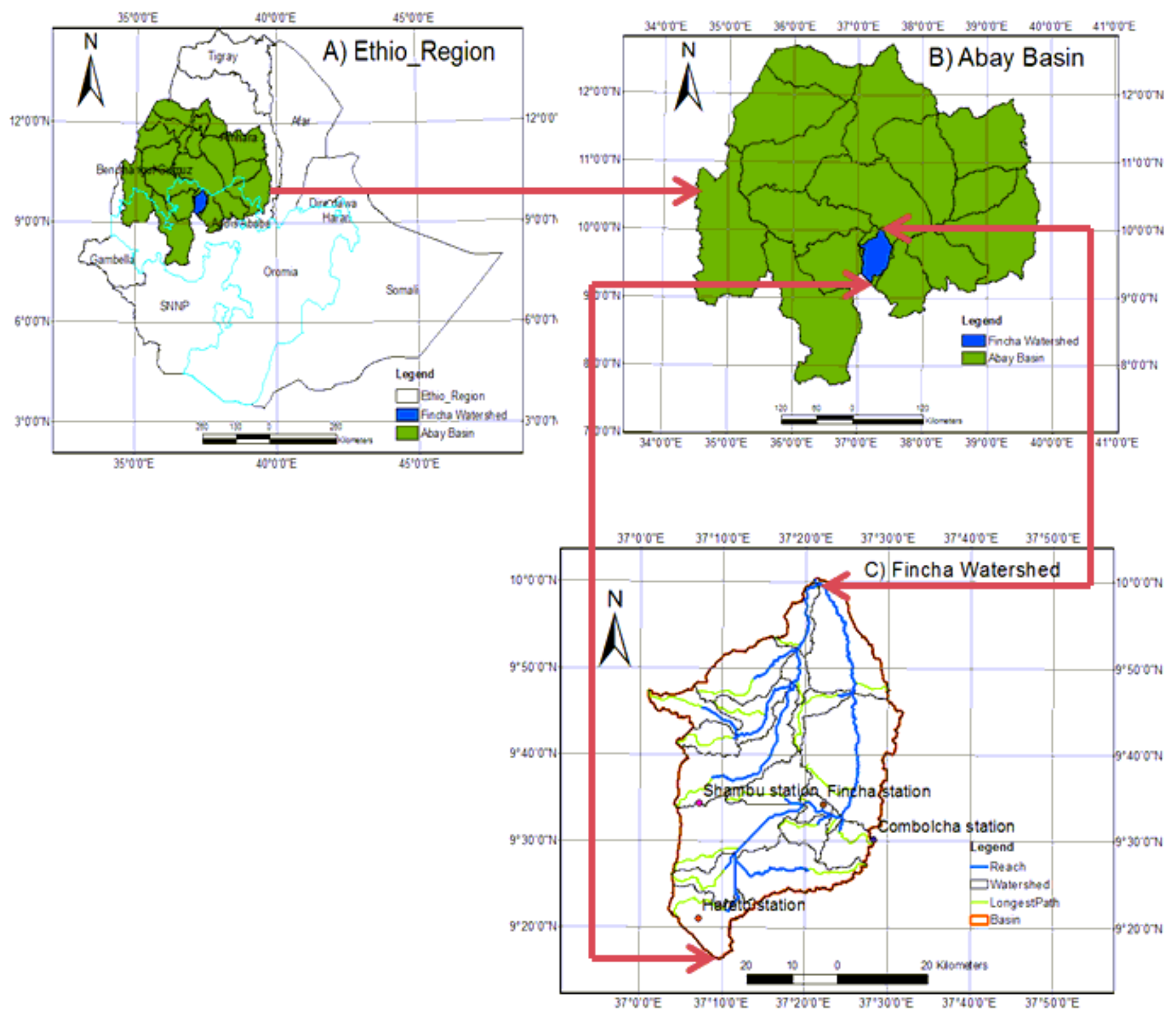

Figure 1

Map of the study area 


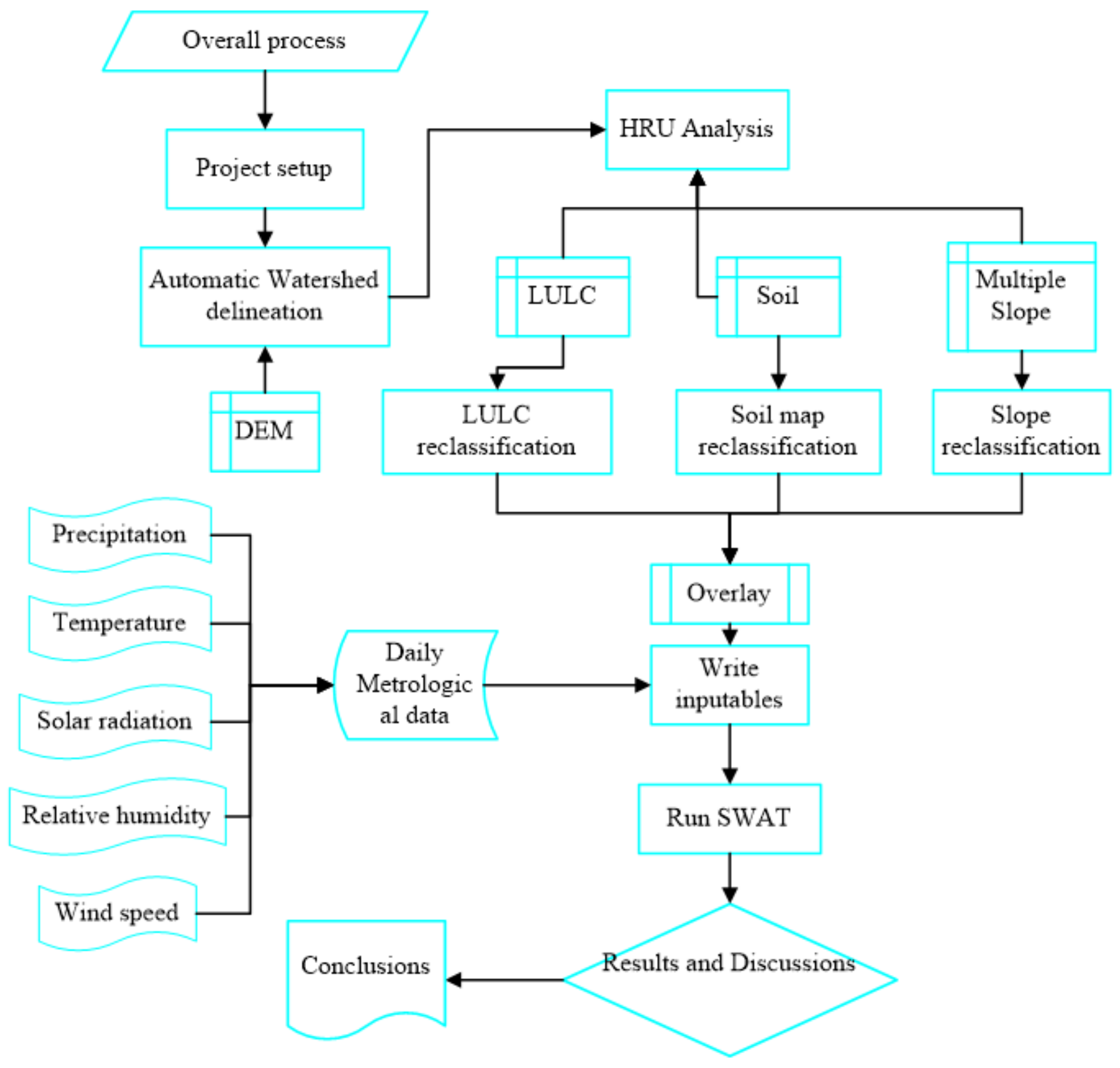

Figure 2

General framework of methodology used 


$37^{\circ} 0^{\prime} 0^{\prime \prime E} \quad 37^{\circ} 15^{\prime} 0^{\prime \prime E} \quad 37^{\circ} 30^{\prime} 0^{\prime \prime} \mathrm{E} \quad 37^{\circ} 45^{\prime} 0^{\prime \prime} \mathrm{E} \quad 38^{\circ} 0^{\prime} 0^{\prime \prime} \mathrm{E}$

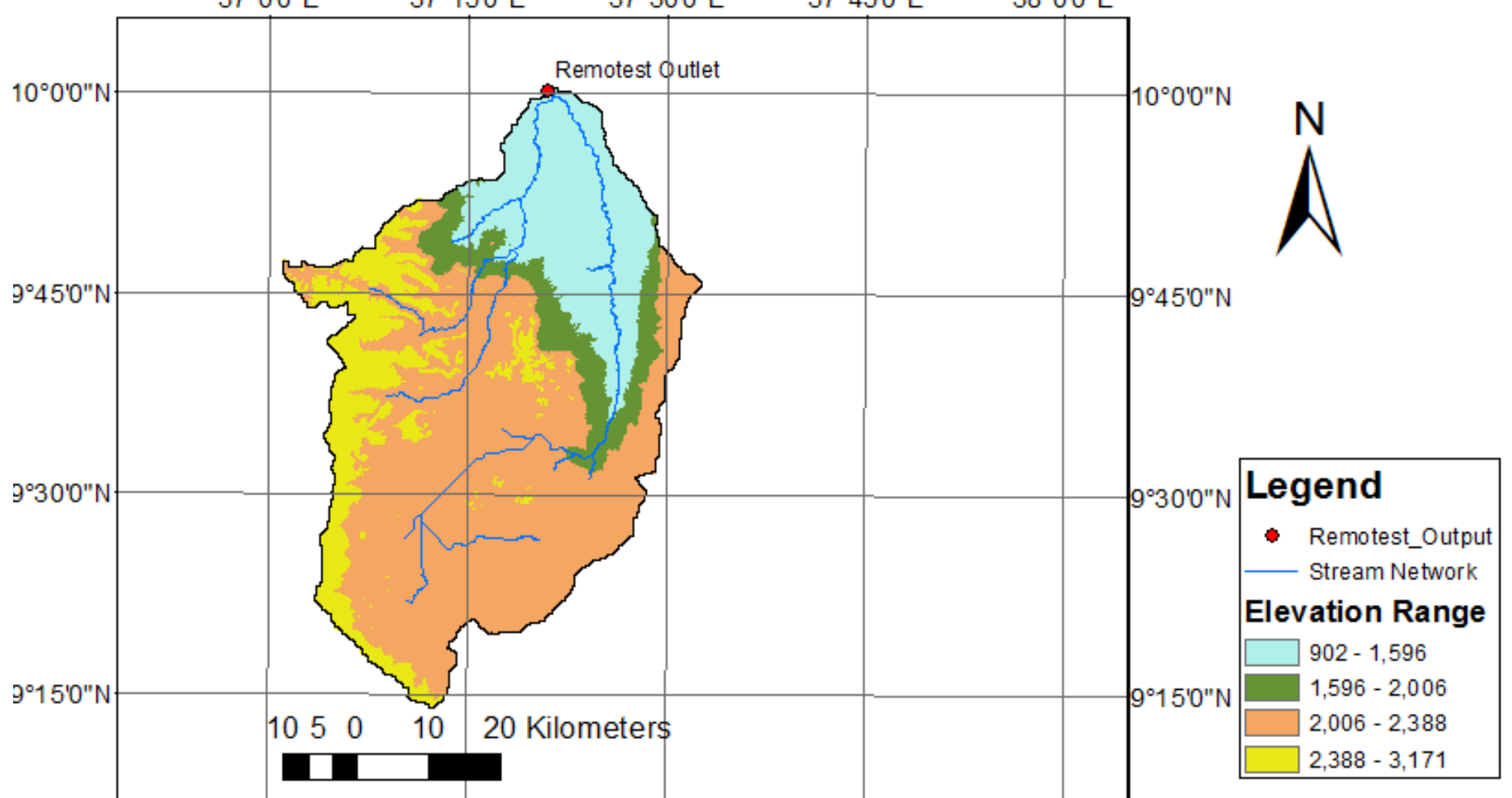

$37^{\circ} 0^{\prime} 0^{\prime \prime}$ E $\quad 37^{\circ} 15^{\prime} 0^{\prime \prime E} \quad 37^{\circ} 30^{\prime} 0^{\prime \prime E} \quad 37^{\circ} 45^{\prime} 0$ "E $\quad 38^{\circ} 0^{\prime} 0^{\prime \prime E}$

Figure 3

Topographic map of Fincha watershed 

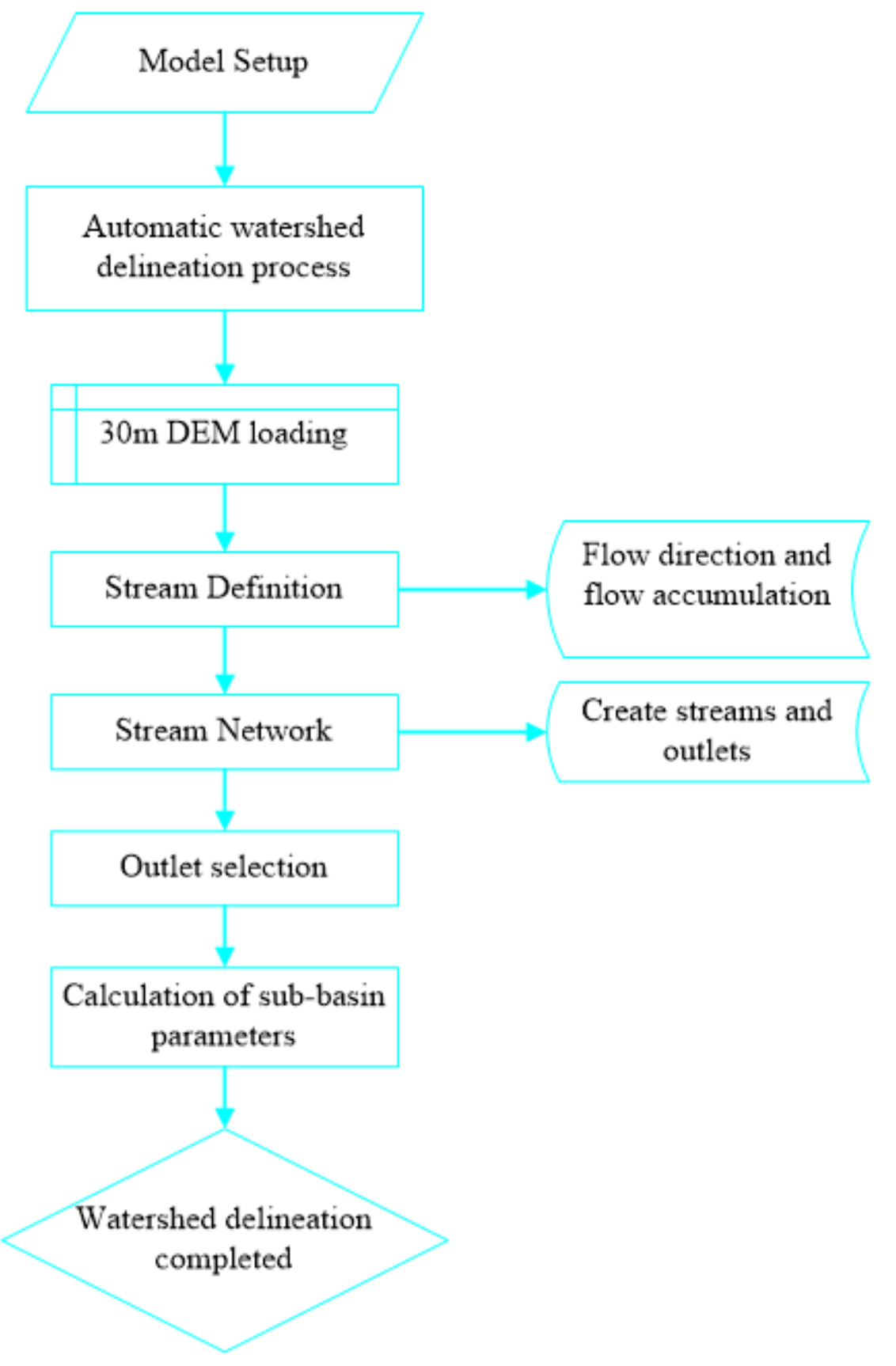

Figure 4

General procedure of Fincha watershed delineation process 


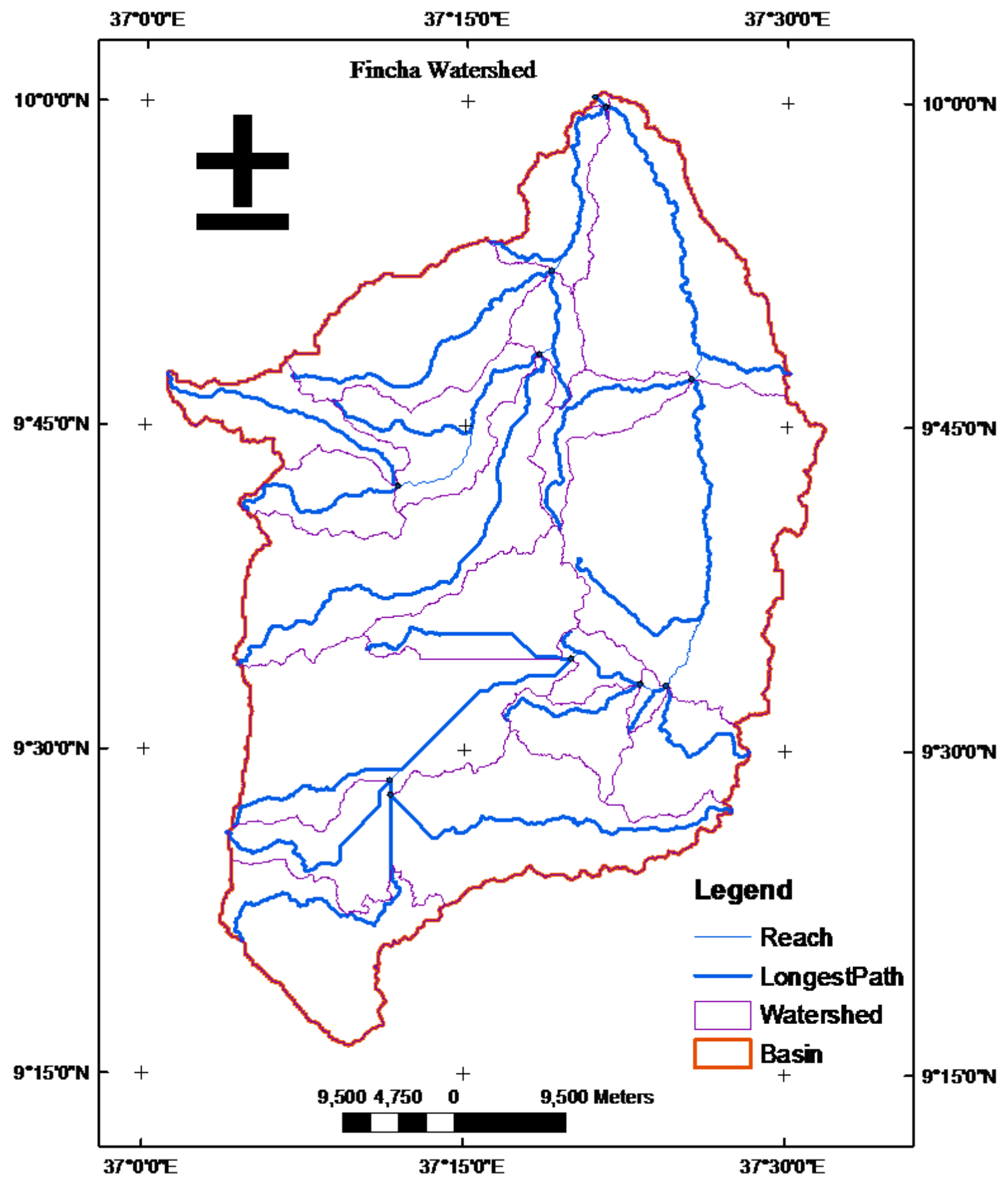

Figure 5

Delineated watershed and sub-basins of Fincha watershed 


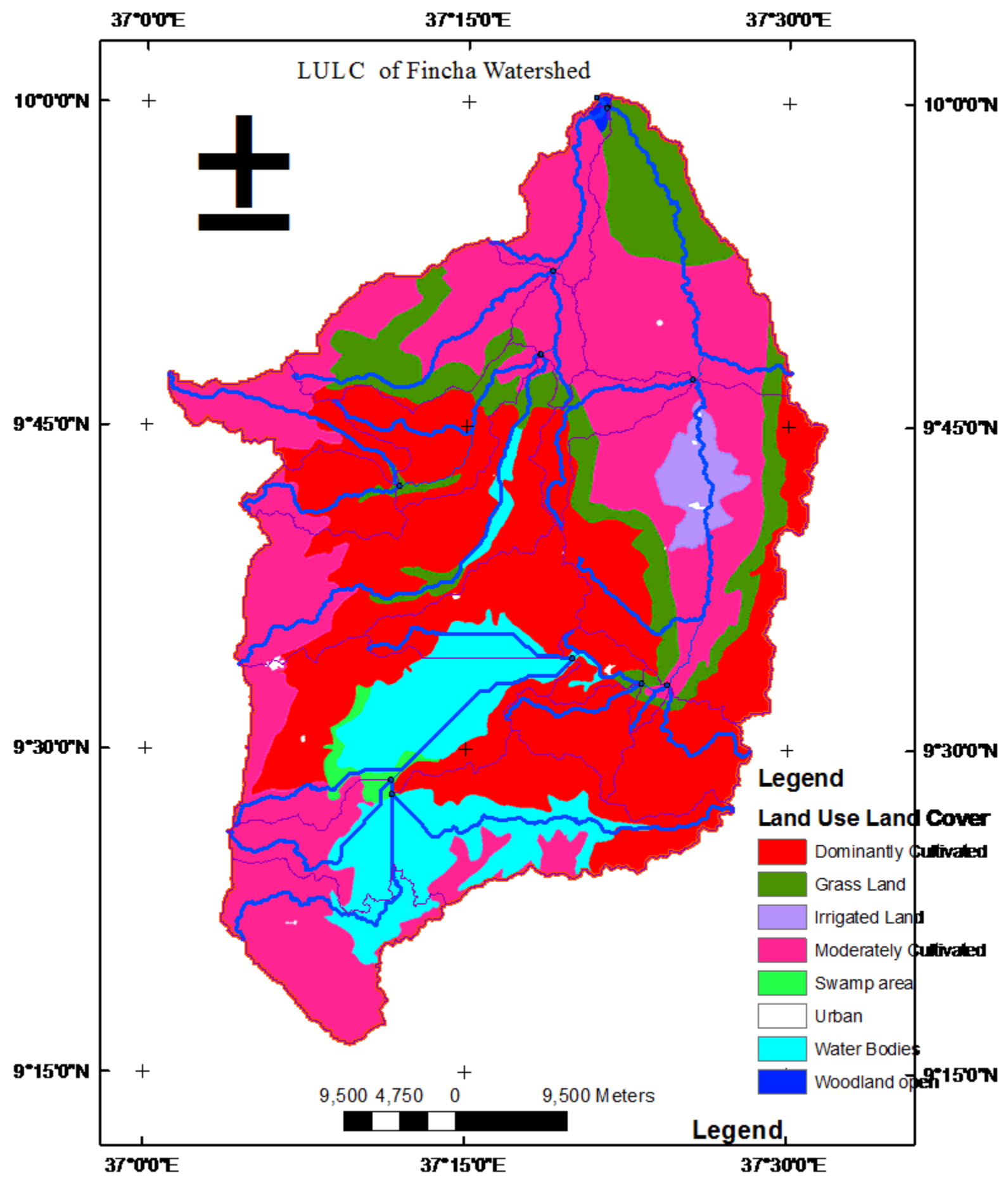

Figure 6

Major land use classes in Fincha watershed 


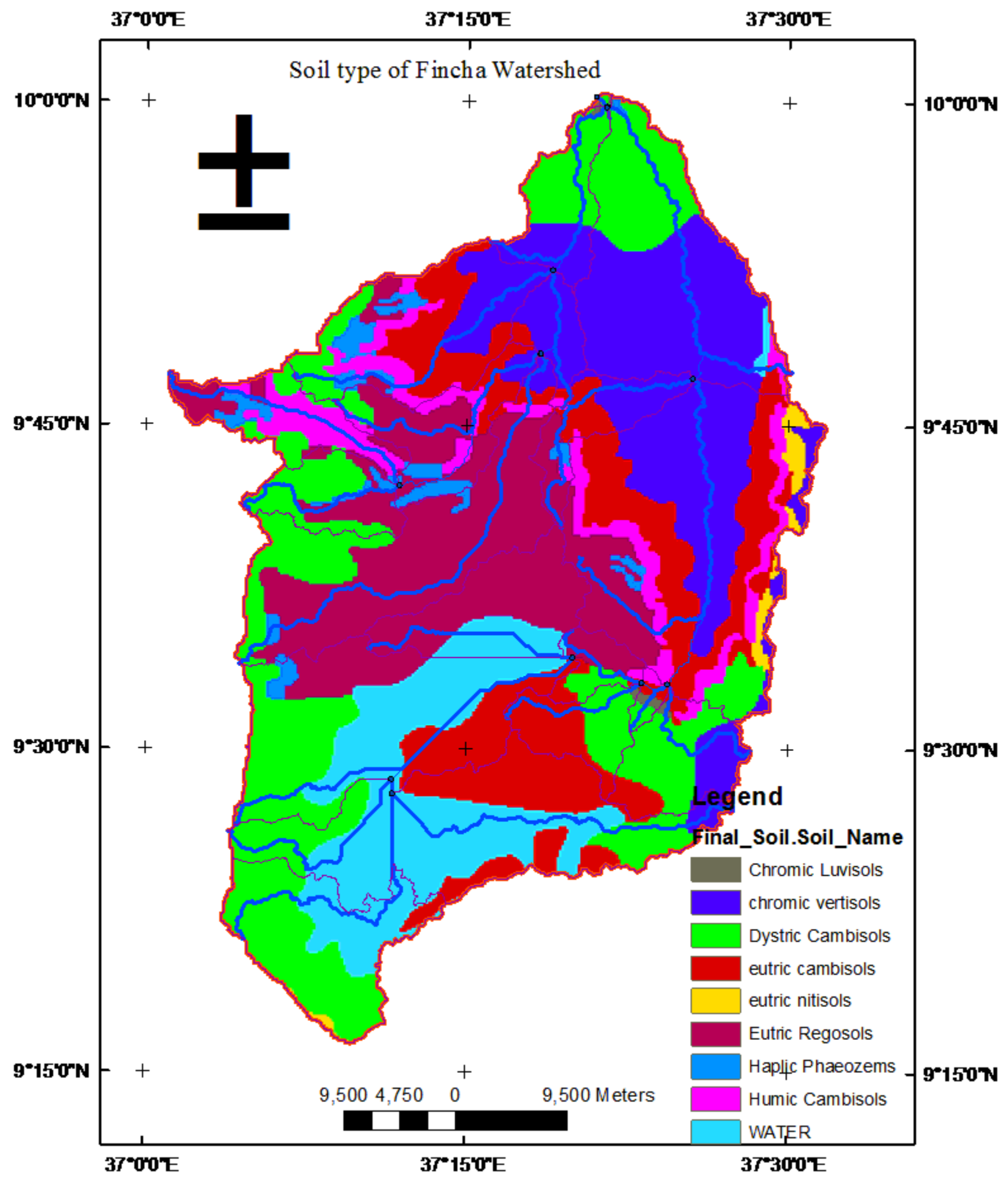

Figure 7

Major soil classes of Fincha watershed 


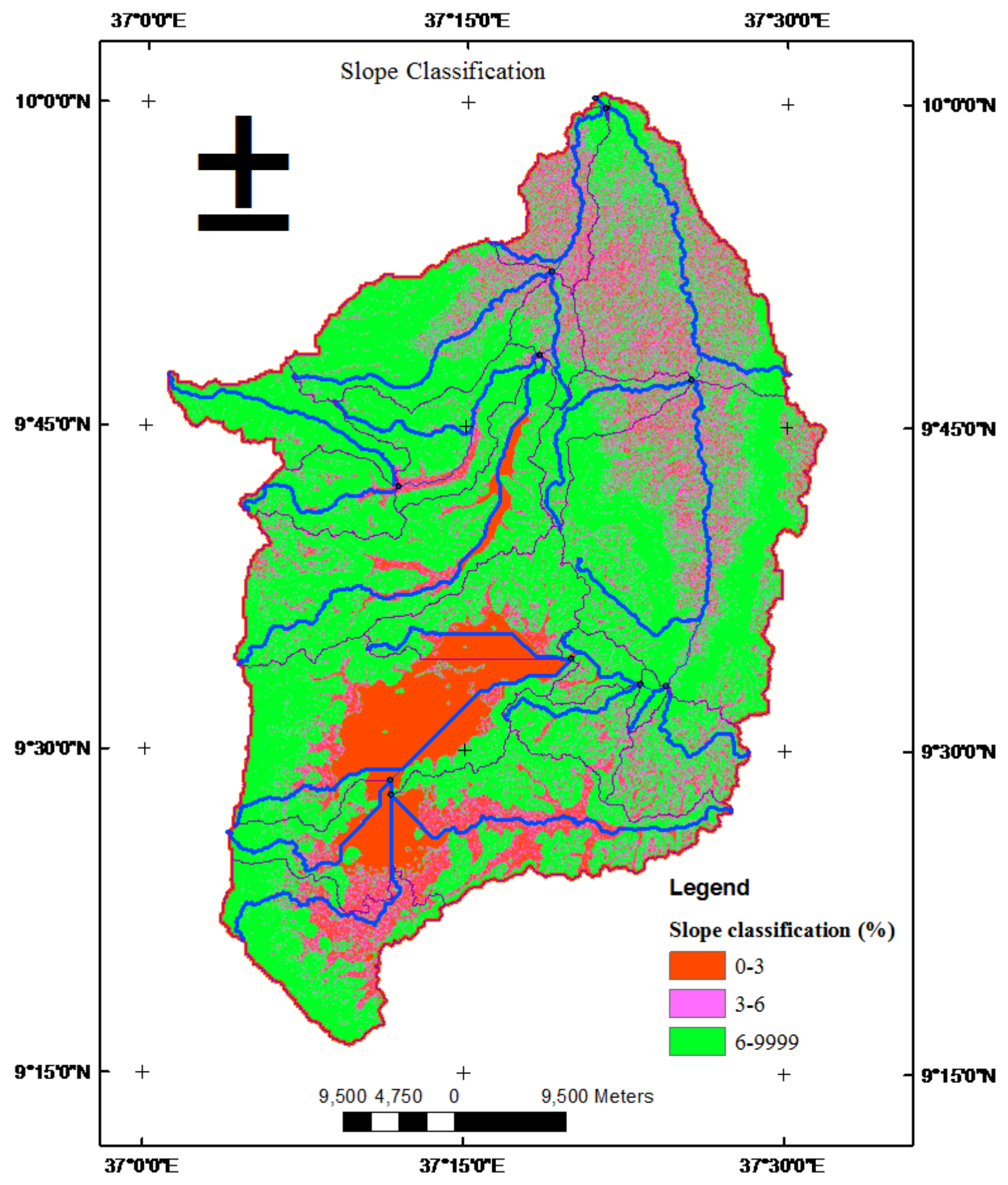

Figure 8

Slope classes of Fincha watershed 


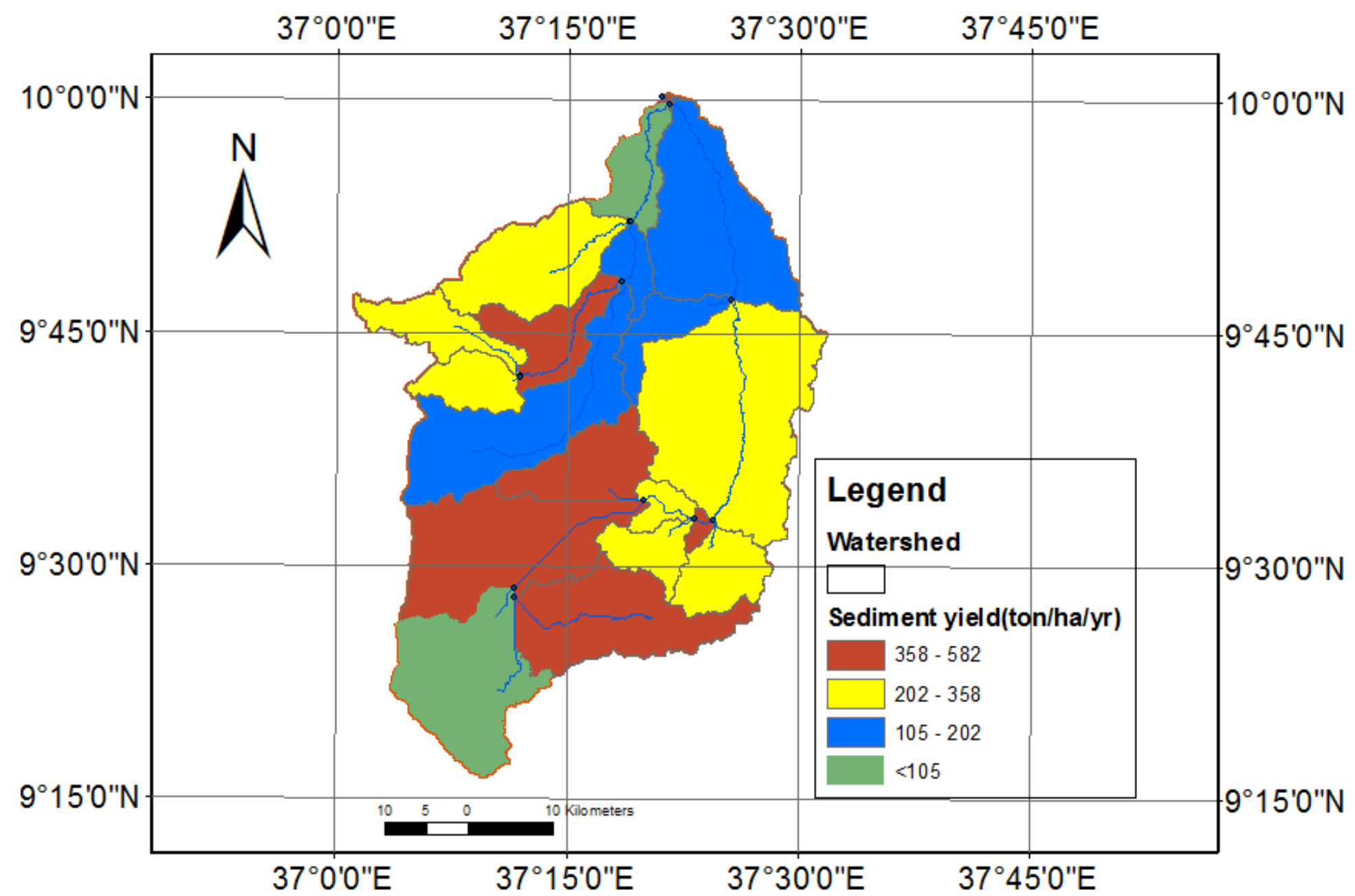

Figure 9

Spatial distributions of soil losses inFincha watershed 